\title{
Predictions of State and County Top Civil Servants Regarding the Abolition of County State Administration Offices: Two Sides of the Same Coin?
}

\author{
Iva Lopižić \\ University of Zagreb, Faculty of Law, Croatia \\ iva.lopizic@pravo.hr \\ orcid.org/0000-0002-1157-0602 \\ Romea Manojlović Toman \\ University of Zagreb, Faculty of Law, Croatia \\ romea.manojlovic@pravo.hr \\ orcid.org/0000-0002-0292-0180
}

Received: 13.11. 2020

Accepted: 22. 3. 2021

\section{ABSTRACT}

In January 2020, county state administration offices, as first-line state administration offices in Croatia, were abolished and their competences transferred to county second-level units of local self-government. This organizational change represents administrative decentralization. The purpose of this article is to examine whether there are any differences in the predictions regarding the effects of this organizational change between two groups of civil servants: state civil servants (heads of county state administration offices and heads of their internal organizational units) and county civil servants (heads of county organizational units), and which are the factors that shape their predictions. A questionnaire was sent to the respondents in June 2019. The statistical analysis of the data (response rate $52 \%$ ) shows a statistically significant difference between the predictions of the two groups in relation to all four categories of effects of this organizational change (inputs, processes, outputs, and outcomes). There is only one point where there is no difference: both groups agree that the county governor's role will grow. The difference in predictions is explained by two factors of cognitive biases: the organization's interest to survive and expand its power, and uncertainty (strategic, structural, and job-related). The paper offers an academic contribution to the field of administrative decentralization by giving insights into the predictions of different actors on the effects of such change before its implementation 
and by introducing factors of cognitive biases as explanations for discrepancies in the predictions.

Keywords: civil servants' predictions, abolition of county state administration offices, administrative decentralization, factors of cognitive biases

JEL: $H 83$

\section{Introduction}

Reallocation of public tasks among different levels of government through decentralization measures is a trend that has been characterizing European states for the last few decades. European countries pursue different strategies of reallocation of public tasks, varying from political and administrative decentralization to deconcentration. While political decentralization relates to the complete transfer of state functions to local self-government units who's democratically elected representative bodies have full powers over their regulation, financing, and execution, administrative decentralization represents only a moderate way of restructuring intergovernmental relations in which local self-government units do not have regulatory powers over the transferred state functions. Administrative decentralization is called incomplete, false decentralization and it leads to differentiation between two groups of local selfgovernment affairs: delegated affairs (übertragen) that local units execute for the state government under restricted autonomy, and self-governing affairs that local units autonomously regulate and execute. Deconcentration involves the transfer of state administration tasks from the central level to local level state administration organizations (Kuhlmann et al., 2014, pp. 205-207). The effects of such intergovernmental changes, especially those related to the performance of decentralized/deconcentrated tasks, have been the subject of a considerable amount of recent research aimed at conceptualizing decentralization effects and testing them in a series of empirical studies of decentralization effects in European countries (Reiter et al., 2010; Kuhlmann and Wollmann, 2011; Ebinger et al., 2011; Kuhlmann et al., 2014; Kuhlmann, 2015; Ebinger and Richter, 2015; Kuhlmann and Wayenberg, 2016).

After a decade of "decentralization silence", Croatia's new State Administration System Act adopted in June 2019 introduced changes in Croatian intergovernmental settings. County state administration offices, as first-instance state administration bodies, were abolished and their tasks (except for supervisory and inspection tasks that were linked to central state administration) were transferred to the counties - Croatian second-level local self-government units. The tasks were transferred to the counties' delegated scope of competence, authorizing counties only for their execution while the central state retained its regulatory authority over the transferred tasks. The transfer of tasks to county government represents an organizational change in the form of administrative decentralization. This paper aims to assess whether the predictions of state (heads of county state administration offices and heads of their internal organizational units) and county (heads of counties' 
organizational units) civil servants regarding the effects of administrative decentralization differ and what factors shape these predictions.

The paper assumes that subjective factors which have been recognized as important in shaping civil servants' attitudes, behaviors, and judgments (Battaglio et al., 2018) influence their predictions, resulting in the different views that state and county civil servants hold on this organizational change. The two factors of cognitive biases considered to be relevant for creating different predictions of state and county civil servants, drawn from organization theory, are (i) the organization's interest to survive and expand its power, and (ii) uncertainty as a feature of every organizational change. Analysis of these factors enabled the formulation of a theoretically grounded hypothesis that the predictions of state and county civil servants on the effects of this organizational change would differ.

The categorical apparatus used to conceptualize indicators to measure civil servants' predictions is derived from the literature on the performance evaluation of decentralization measures (Reiter et al., 2010; Kuhlmann and WolImann, 2011; Ebinger et al., 2011; Ebinger and Richter, 2015; Kuhlmann, 2015; Kuhlmann and Wayenberg, 2016) and upgraded by new indicators. The predictions of civil servants are examined concerning four categories of effects (inputs, processes, outputs, and outcomes). The data on civil servants' predictions were gathered by a questionnaire sent to the heads of the respective organizational units in June 2019, a few months before the organizational change was implemented. The response rate to the questionnaire was $52 \%$. The gathered data were statistically analyzed to determine whether there is a statistically significant difference between the answers of the two groups of respondents.

The theoretical contribution of the paper is twofold. First, it gives an overview of the factors of cognitive biases that might shape the predictions of state and county civil servants on the effects of the organizational change. Second, it contributes to the body of literature dealing with decentralization, particularly administrative decentralization, by offering insights into predictions related to the effects of administrative decentralization conducted in the Croatian context.

\section{Abolition of county state administration offices and administrative decentralization in 2019}

Until January 2020, the Croatian state administration system comprised central (ministries, state administration organizations, and state offices) and first-instance (county state administration offices - uredi državne uprave $u$ županijama) state administration bodies. County state administration offices as first-instance state administration bodies were established in 2001 and were organized in each county to act in parallel with the institutions of county self-government administration. The county state administration offices' legal status was regulated by state administration system acts (Official Gazette 
nos. 75/93, 48/99, 15/00, 127/00, 59/01, 119/03, 79/07; Official Gazette nos. $150 / 11,12 / 13,93 / 16,104 / 16)$ and Government decrees. The head of county state administration offices (predstojnik) was appointed by the Government on the proposal of the Minister of Public Administration based on public recruitment and the offices were responsible to the Ministry of Public Administration. Mostly, they were internally organized into four or five organizational units. An analysis of their institutional development showed that their role in territorial management had been decreasing over time, both in relation to their personnel and financial capacity and their scope of competence so the abolition of the offices might be considered as the natural end of their institutional path (Lopižić, 2020). According to an analysis of their scope of competence (Lopižić, 2020), there were 69 tasks assigned to county state administration offices in 2018, most of them in the area of general administration, education, culture, and social services. Unlike other first-instance state administration bodies in European countries that perform more tasks of a planning and coordinative character (see Bjorna and Jenssen, 2004; CoE, 2015), almost all of the tasks performed by county state administration offices were of an implementing nature. An insight into county state administration offices' actual activities shows that they were predominantly engaged in general administration and resolving citizens' status rights $(83.1 \%$ of resolved cases in 2015) (Ministry of Public Administration, 2016). Thus, the role of county state administration offices consisted of the execution of very detailed and exhaustive state regulations without any influence on the policy-making of the central state or their adaptation to specific local interests or groups of users (Lopižić, 2020).

Counties (županije), as second-level local self-government units in Croatia, were created in 1993. The status of the counties is regulated by the Act on Local and Territorial (Regional) Self-Government (Official Gazette, nos. $33 / 01,60 / 01,129 / 05,109 / 07,125 / 08,36 / 09,36 / 09,150 / 11,144 / 12,19 / 13$, $137 / 15,123 / 17,98 / 19,144 / 20)$ and they are headed by the county assembly (županijska skupština) as a legislative body, and a directly elected governor (župan) as an executive body. Although Croatia has five historical regions (Koprić et al., 2017), twenty counties were created to weaken the local selfgovernment system and create units easily controllable from the centre. The territorial boundaries of counties were tailored according to political necessities, resulting in great disparities in their size, population density, and economic activity (Koprić, 2010, p. 672). The Croatian local self-government system is still highly centralized with an overall share of local self-government units in public expenditure of $26 \%$ (UCLG, 2016). The counties' share is even lower than those of local units: in 2018, they had a share of $15.3 \%$ in total local revenues and $15.6 \%$ in total local expenses (Ministry of Finance, 2019) which indicates their low financial capacities. Their capacity varies considerably among counties (Croatian Chamber of Commerce, 2018, p. 5). An examination of their internal organizational structure and the number of county civil servants per county inhabitant shows great disparities among counties in these aspects, too (Đulabić, 2018). 
Counties have so far been the main "winners" of decentralization measures in Croatia (Koprić and Đulabić, 2018, p. 255). They took over decentralized tasks in firefighting (1999), healthcare, education, and social care (2001), the issuing of building permits, spatial planning, and maintenance of public roads (2007), and environmental protection (2008 - onwards). However, these decentralization measures represented "False decentralization", leaving counties and other local units that took over the tasks without real influence on the provision of decentralized tasks and not changing to any great extent their position regarding decentralized functions (Koprić, 2014, p. 139). The evaluations of decentralization measures show that counties are highly dependent on central state grants for decentralized functions to become "financial branches of the state" (Jambrač, 2017, p. 212), with growing disparities in their capacity to perform decentralized tasks (Jambrač, 2017) which has ultimately led to increasing social inequalities (for social services) (Babić, 2018). The very existence of counties, their poor performance, and the necessity to transform them into real regions has been a topic of discussion since their creation in $1993 .^{1}$

The county state administration offices were abolished in January 2020 and their competences were transferred to the county (županije) delegated scope of competence. The abolition of the offices was introduced by a new State Administration System Act (SASA - Official Gazette, no. 66/19) adopted in June 2019 that was followed by the amendments of sectoral laws in October 2019. The aims of the abolition of county state administration offices were decentralization by the transfer of tasks to the counties' delegated scope of competence and rationalization of the state administration system by reducing the number of state administration bodies and state civil servants (Croatian Government, 2019, p. 20). Counties took over all the tasks performed by the offices, except supervisory and inspection tasks that were affixed to central state administration bodies, as well as nearly 2,000 officials working in the offices. Due to this organizational change, the number of county civil servants almost doubled. ${ }^{2}$ According to the SASA, the county governor, as the holder of executive power in the counties, is responsible for the execution of the transferred tasks (Art. 35 SASA). The execution of the transferred tasks is supervised in the regime of administrative supervision where central state bodies are entitled to supervise the legality and regularity of the work and treatment of citizens and other parties, and civil servants' competence for the direct performance of state administration tasks (Art. 25 SASA).

\section{Theoretical framework and hypothesis}

The main research question of the paper is whether the predictions of state and county civil servants on the effects of the abolition of county state ad-

1 For an overview of such arguments, see Koprić et al., 2017, pp. 61-69.

2 In 2018, 2,276 people were working for county government (Ministry of Finance, 2019) compared with almost 2,500 people working for county administration offices. 
ministration offices and the transfer of their tasks to the counties' delegated scope of competence differ and, if so, which factors shape the predictions.

Predictions, as the estimations of future events, are based on the objective knowledge of a certain phenomenon and existing circumstances and their causal relation with future outcomes. Reasoning based on knowledge, information, experience, and logical evaluation is emphasized by rational choice and decision-making theories that view individuals as rational actors who behave in conditions of perfect certainty. The rational model of human behaviour is contested in behavioural studies (Barros, 2010; Wheeler, 2018) as well as in organization theory, resulting in the concept of bounded rationality due to the limited knowledge and computational capacity of organizational members (Simon, 1990). Comparative empirical studies on the effects of decentralization indicate that national specificities, especially the main features of local self-government systems and the nature of transferred tasks, play a great role in the realization of decentralization effects (Reiter et al., 2010; Kuhlmann and Wollmann, 2011; Ebinger et al., 2011; Kuhlmann et al., 2014; Kuhlmann, 2015; Ebinger and Richter, 2015; Kuhlmann and Wayenberg, 2016). Reasoning, even in the context of bounded rationality, based on objective factors about the main features of Croatian local self-government systems and the nature of tasks transferred from county state administration offices to counties should lead to similar predictions by both state and county civil servants. Taking into account the characteristics of Croatian territorial government, it could be assumed that the effects of administrative decentralization would be low.

The extensive analysis by Battaglio's et al. (2018) of scientific papers on factors that shape the attitudes of civil servants shows that cognitive biases systematically affect public policy and management decisions, as well as civil servants' preferences, estimates, judgements, and behaviours. In this paper, two groups of factors of cognitive biases that may affect civil servants' predictions on the effects of administrative decentralization are considered: (i) the organization's interest to survive and expand its power, and (ii) uncertainty as an accompanying feature of every organizational change. It is assumed that these two factors may have a distinctive effect on shaping predictions of the two categories of respondents (state versus county civil servants), and thus are relevant for the formulation of the hypothesis.

The primary goal of every organization to conserve its own existence and expand or increase its power is expressed in ecological theories of the organization (Bidwell and Kasarda, 1998) and pictured in Morgan's (2006, pp. 33-70) image of the organization as an organism that constantly needs to adapt to its environment in order to progress and survive. As explained by the political control approach to the termination of public organizations, public administration organizations are highly dependent on political interests, unlike private organizations that primarily depend on their own strategies to survive (Kuipers et al., 2018). The conservation of public organizations may become a goal of the politicians and civil servants working in them, regardless of the 
broader public interest (Koprić et al., 2014, p. 10; Morgan, 2006, pp. 248-251). This point of view suggests that the abolition of county state administration offices could provoke the primary impulse of state civil servants to protect their own organization no matter what outcomes the abolition would have on the provision of public services. At the same time, it suggests that county civil servants might hold a positive view on the abolition of county state administration offices. Due to this organizational change, the number of civil servants working in county government would almost double which significantly reduces the possibility of the reorganization of county self-government through a reduction of their number which is advocated by public administration scholars who claim that Croatia should be organized in a smaller number of regions as second-level local self-government units (Koprić, 2015; Đulabić, 2015).

Improving an organization's power is another factor that may shape the positive predictions of county civil servants about the abolition of county state administration offices. Heads of county offices could expect their position and powers to expand since the newly integrated state civil servants could come under their jurisdiction, and their organizational unit could consequently grow in size and importance. They would gain control in resolving administrative matters in new administrative areas and thus have greater influence on the social life of their local units (especially in the area of small and medium-sized enterprises) (Koprić, 2019, p. 12). This is supported by the fact that the tasks of county state administration offices were transferred solely to the county government and not to other local units with sufficient capacities to take on the tasks (i.e. big towns although they asked for these tasks). Additionally, ex ante evaluation of the abolition of county state administration offices showed that the main reason for this organizational change was to strengthen the role of counties in the Croatian political-administrative system and to prevent attempts to abolish them or reduce their number (Lopižić and Manojlović Toman, 2019). The eagerness of counties to take over the tasks of county state administration offices could also be explained by strategic rationality ("the civil servant prefers the prime responsibility for policy areas to lie at the level where he or she is working, especially when he or she is directly involved in this policy area"), as stated by de Vries $(2013$, p. 11) which speaks in favor of taking responsibility for new tasks.

Each organizational change is accompanied by the uncertainty that civil servants experience during the process which results in fears, anxieties, and resistance to change (de Vries, 2013, p. 3). In this particular case, it is expected that state civil servants face greater amounts of uncertainty than county civil servants in relation to all dimensions of uncertainty (strategic, structural, and job-related) as defined by Bordia et al. (2004).

Strategic uncertainty refers to "uncertainty about reasons for change and the future viability of the organization, in addition to uncertain business environments" (Bordia et al., 2004, p. 510). The abolition of county state administration offices has not been anticipated in any strategic document on the future 
development of Croatian public administration. ${ }^{3}$ Moreover, these documents proposed the strengthening of county state administration offices by merging ministerial branch offices into their structure. The reform was prepared in a few months and, until the last moment, it was not specified when the offices would be abolished which probably led to great uncertainty for civil servants working in county state administration offices. Counties experienced strategic uncertainty as well, but to a lower degree. A certain amount of uncertainty there stemmed from the fact they did not know how many state civil servants would be transferred to their administration or how they would be financed from the state or their own budget. However, this organizational change did not jeopardize the future or future visibility of their organization, which might have given them some security.

Structural uncertainty refers to "changes to the inner workings of the organization, such as reporting structures and functions of different work-units" (Bordia et al., 2004, p. 510). Due to this organizational change, state civil servants were to be moved from county state administration offices with a highly uniform organizational structure to county administration that is highly diversified among counties, both in relation to the number of civil servants per county inhabitant and the internal organizational structure (Đulabić, 2018, pp. 459-464). They did not know whether their organizational unit would be organized as an independent county office or merged with other county offices. They would have to adopt new working practices and routines and adapt to probably different organizational cultures. Furthermore, as threatrigidity theory suggests, the two dominant methods organizations employ to deal with threatening events are the centralization of control and an increase in the level of formalization in the organization (Wynen et al., 2019, pp. 7-8). Since state civil servants were those entering into new organizations, it was expected that the counties would adopt centralizing and formalizing practices for the newly integrated state civil servants, requiring them to change their working methods and adopt them to fit those existing in the counties, which could have increased their level of uncertainty. Supervision over the execution of the public tasks, however, remains the same since the SASA prescribes an identical supervision procedure over county state administration offices and county self-government units in the execution of the transferred tasks.

Job-related uncertainty refers to "uncertainty regarding job security, promotion opportunities, changes to the job role, etc." (Bordia et al., 2004, p. 510). It was expected that state civil servants, especially those in higher positions, would face a high degree of uncertainty since they did not know whether they would retain their leading positions or become subordinated to the heads of county offices. Losing their managerial position could be considered to have very negative implications that might have led to strong opposition to organizational change (Huerta Melchor, 2008, p. 16). The legal status of state civil servants was not to change considerably since the Act on Civil

3 Strategy on the Development of Croatian Public Administration 2015-2020; The Action Plan of the Croatian Government 2017-2020; The Strategic Plan of the Ministry of Public Administration 2019-2021. 
Servants and Employees in Local and Territorial (Regional) Self-Government (Official Gazette, nos. 86/08, 61/11, 04/18, 112/19) follows the provisions established in the Act on State Civil Servants (Official Gazette, nos. 92/05, 140/05, 142/06, 77/07, 107/07, 27/08, 34/11, 49/11, 150/11, 34/12, 49/12, $37 / 13,38 / 13,01 / 15,138 / 15,61 / 17,70 / 19,98 / 19)$ (Marčetić, 2013). Thus, the legal rules regulating their behaviour remain basically the same. However, there was a positive implication related to their position because the salary of most civil servants transferred to counties was to grow since the salaries in county administration are higher than those in state administration. The job uncertainties faced by county civil servants are somewhat lower since their position is not expected to change. This is in line with the empirical study conducted by de Vries (2013) who examined the effects of the reorganizations of Dutch municipalities and provinces. His research showed that civil servants that were in doubt whether they would keep their present job showed "less satisfaction with the organization they are working for, less positive attitudes about politicians and politics, less public service motivation, more criticism about the performance of their colleagues, less affinity to their organization and less pride in their work".

The overview of factors that may influence predictions of the two categories of respondents allows the following hypothesis to be formulated:

$\mathrm{H}$ : State civil servants' predictions on the effects of the abolition of county state administration offices differ from the predictions expressed by county civil servants.

\section{Research Methodology}

\subsection{Indicators}

In contemporary literature on decentralization (Reiter et al., 2010; Kuhlmann and Wollmann, 2011; Ebinger et al., 2011; Kuhlmann et al., 2014; Kuhlmann, 2015; Ebinger and Richter, 2015; Kuhlmann and Wayenberg, 2016), the performance effects of administrative decentralization are evaluated through three dimensions: inputs (democratic control and accountability, transparency), processes/procedural aspects (horizontal and vertical coordination), and outputs (efficiency, effectiveness, and homogeneity of delivered services). This paper follows the aforementioned division into three dimensions (inputs, processes, and outputs) and develops indicators for each category. However, these categories are extended with the category of outcomes following KuhImann and Wollmann's (2011, p. 481) division of three steps or "loops" in the evaluation of institutional reforms at the subnational level ${ }^{4}$ and the classical production model of performance that consists of the input-process-output-

4 They explain that the first step ("loop") consists of identifying whether and why certain institutional changes have taken place. In the second step, an evaluation of the changes that the institutional reform has brought about in the operation ("performance") of organizations under consideration is conducted (performance evaluation). The last step or "loop" is outcome evaluation, where the outcomes of the reforms are sought. 
outcome relationship (Van Dooren et al., 2015, p. 21). Outputs are considered to be only those results on which the organization has a direct influence. According to Bouckaert and Halligan (2008, p. 16), outputs are never an end in themselves in public organizations. These organizations have to be oriented towards long-term outcomes that are of vital importance for citizens. Outcomes can be divided into intermediate (short-term) and final (long-term) outcomes. However, the problem with outcomes is that they are never the sole product of a certain organization, but the context (environment) has an impact on them, particularly on final, long-term outcomes (Van Dooren et al., 2015, p. 24).

In this paper, the input dimension refers to effects related to the democratic control and accountability of counties, including the potential growth in the importance/influence of the county representative/executive body, the greater involvement of citizens and other stakeholders in the decision-making process, and greater transparency. The process dimension refers to the effects related to horizontal and vertical coordination, including coordination within the counties that took over tasks, coordination between the county and other public bodies, and the influence and control of the central government over counties. The output dimension refers to effects related to the efficiency and quality of public services among counties, including financial and personnel costs, the availability and expediency of delivering services to citizens, strengthening the professionalism of county officials, as well as the use of new managerial techniques such as strategic planning, digitalization, etc. Outcomes are defined in a threefold manner: overall citizen satisfaction which should be the goal of every institutional change, ensuring the equity of citizens which is one of the basic values in public administration, and fostering regional development which is one of the primary roles of second-level selfgovernment units (see Table 1). 


\section{Table 1: Research dimensions and indicators}

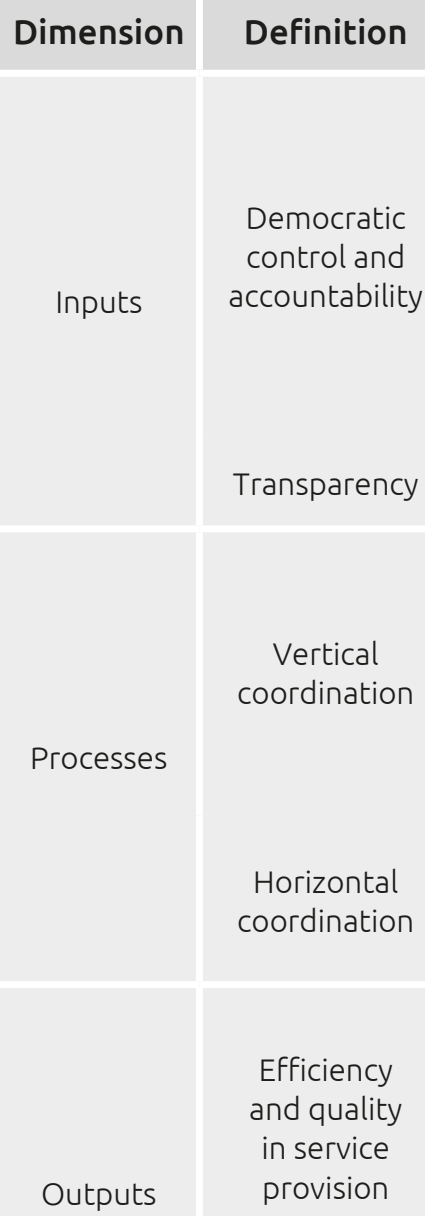

Modernization of county public management

Citizen
satisfaction

Outcomes

Equity of

\section{Indicators}

I1 Citizens will show greater interest in the work of the county's administrative bodies and the county's governor 12 Higher level of citizen participation in the work of the county's administrative bodies (petitions, submitting proposals, citizen assemblies, etc.)

13 Growth in the importance of the county's representative body 14 Growth of the county governor's role

15 Higher turnout for elections for the county's representative body and governor

16 Increase of transparency of the county's administrative bodies (publication and availability of information)

17 Supervision of the central state over the counties' tasks is of higher quality and uniformity

I8 Supervision of the central state over the counties' tasks is of higher intensity

19 Higher level of collaboration between the counties and the local units on their territory

I10 Better collaboration between counties and central state bodies

I11 Better coordination within the counties' bodies

I12 More intensive collaboration among the counties

I13 Better collaboration with branch offices of central state bodies and other public bodies on the territory of the county

I14 Decrease in expenditure for providing decentralized public services

I15 Speeding up the provision of decentralized public services I16 Increasing the number of services provided in decentralized areas of services

I17 Better quality of services through better education of civil servants

18 Increasing/starting to implement new work techniques and instruments (i.e. use of new technologies, citizens satisfaction surveys, a strategic approach to service delivery)

I19 Increase in citizens' satisfaction with provided services I20 Decrease in the number of appeals and other complaints made by citizens about the decisions of county bodies

I21 Increasing the accessibility of services citizens

I22 Ensuring the equal quality of services over the entire state territory

I23 Ensuring services are adjusted towards specific groups of users

Regional development
124 Increasing the rate of investments in the county

I25 Decreasing the rate of emigration from the county

I26 Increasing the use of EU funds

Source: authors 


\subsection{Methodological Approach}

The predictions of state and county civil servants are examined through a questionnaire that was sent to (a) heads of county state administration offices (20), (b) heads of county state administration offices' internal organizational units (82), and (c) heads of county self-government administration bodies (180). As the heads of the main organizational units of the county state administration offices and county government, these state and county civil servants have the broadest knowledge on the present situation in the Croatian political-administration system, its strengths, and weaknesses. Thus, they represent a proper sample to examine whether some of the examined subjective factors of cognitive biases can influence their predictions. However, one should keep in mind that, as some research has shown (Frazier and Swiss, 2008; Van de Walle et al., 2016, p. 18), top civil servants might have a better opinion of their organization's performance than lower-ranked civil servants. For this reason, the predictions of the surveyed civil servants cannot be considered as the general attitude of their organizations.

The questionnaire was distributed in June 2019, a few months before the formal abolition of county state administration offices. Since the questionnaire was delivered before the abolition of county state administration offices, the predictions expressed by the respondents were not biased by the actual effects of the implementation. The online questionnaire was distributed, and 148 (52\%) responses were received, out of which 67 responses from state civil servants (categories a and b) and 81 responses from county civil servants (category c).

The respondents had to rank each of the indicators listed in Table 1 and specify the degree to which they predicted that the abolition of the offices and transfer of their tasks to the counties' delegated scope of competence would contribute to the attainment of the indicator. The answers were offered on a four-point Likert scale, with the possibility also to choose "I don't know/don't want to respond". The lowest point (1) indicates that the respondent considers administrative decentralization to have the lowest effect on the indicator (I do not think the abolition of offices will have any effect on...), point (2) indicates that the respondent considers it would have a small effect (I think the abolition of offices will have a small effect on ...), point (3) indicates that the respondent considers it would have a medium effect (I think the abolition of offices will have a medium effect on...) while the highest score was 4 (I think the abolition of offices will have a high effect on...). The results were analyzed through the use of SPSS and the U-test.

\section{Results}

The total number of responses received was 148 (52\% out of 282 questionnaires sent). In the category of state civil servants, the response rate was $65 \%$ (67/102), while in the category of county civil servants it was $45 \%(81 / 180)$. The descriptive statistics show that the most frequent answer given by state civil servants was 2 (I think the abolition of state offices will have a small effect 
on...) and the lowest 1 (I do not think the abolition of state offices will have any effect on....). On the other hand, the most frequent answers given by county civil servants is 3 (I think the abolition of state offices will have a medium effect on...). There are only five indicators where county servants predict that the abolition of state offices will have only a small, limited effect: one from the input category (a higher level of citizens' participation in the work of county offices) and four out of the eight indicators from the outcomes category (a decrease in the number of appeals and other complaints about the decisions of county bodies; an increase in the rate of investments in the county; a decrease in the emigration rate from the county; an increase in the use of EU funds). Taking into account that state civil servants consider that the decentralization effects on these indicators will be even less shows that both categories of respondents predict that the abolition of county state administration offices will have the lowest effect on the outcomes category. There are only two points where the predictions of both categories concur: the fact that the abolition of state offices will have a small effect on the increase in the use of EU funds, and that the abolition will have a high effect (the highest in absolute terms) on the growth of the influence of the county governor's role (Figure 1). Thus, the data stemming from the descriptive statistics seem to confirm the hypothesis, except for the two aforementioned indicators (14 and I26).

Figure 1: Median values of answers

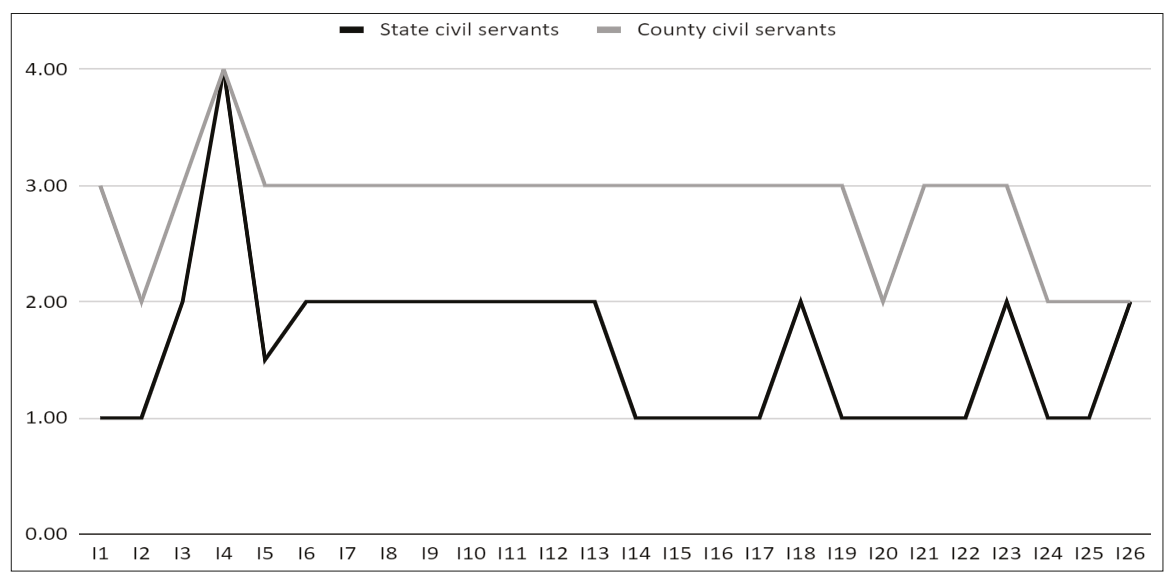

Source: authors

The research results are further elaborated through statistical tests using SPSS (Table 2). The results show that there is a statistically significant difference between the two groups in all respects, except for 14 (growth in the influence of the county governor's role). The results do not change even when single indicators are integrated into broader categories of the research dimensions (inputs, processes, outputs, and outcomes). Thus, the stated hypothesis that state and county civil servants' predictions about the effects of the abolition of county state administration offices differ was statistically confirmed, except for 14. 
Table 2: Statistical analysis

\begin{tabular}{|c|c|c|c|c|c|c|}
\hline & Dimension & Indicator & $\begin{array}{c}\text { Mann- } \\
\text { Whitney U }\end{array}$ & $\begin{array}{l}\text { Wilcoxon } \\
\text { W }\end{array}$ & Z & $\begin{array}{c}\text { Asymp. } \\
\text { Sig. } \\
\text { (2-tailed) }\end{array}$ \\
\hline \multirow{6}{*}{ Inputs } & \multirow{5}{*}{$\begin{array}{l}\text { Democratic control and } \\
\text { accountability }\end{array}$} & $\mid 1$ & 1342.500 & 3620.500 & -5.408 & 0.000 \\
\hline & & 12 & 1583.000 & 3861.000 & -4.486 & 0.000 \\
\hline & & 13 & 1407.500 & 3618.500 & -5.006 & 0.000 \\
\hline & & 14 & 2217.000 & 4362.000 & -1.071 & 0.284 \\
\hline & & 15 & 1552.000 & 3763.000 & -4.282 & 0.000 \\
\hline & Transparency & 16 & 1580.500 & 3858.500 & -4.142 & 0.000 \\
\hline \multirow{7}{*}{ Process } & \multirow{4}{*}{ Vertical coordination } & 17 & 1485.000 & 3763.000 & -4.636 & 0.000 \\
\hline & & 18 & 1622.000 & 3900.000 & -3.983 & 0.000 \\
\hline & & 19 & 1456.000 & 3667.000 & -4.455 & 0.000 \\
\hline & & 110 & 985.000 & 3263.000 & -6.616 & 0.000 \\
\hline & \multirow{3}{*}{ Horizontal coordination } & $\mid 11$ & 1262.500 & 3407.500 & -5.356 & 0.000 \\
\hline & & 112 & 1834.000 & 3914.000 & -3.030 & 0.002 \\
\hline & & $\mid 13$ & 1439.500 & 3717.500 & -4.910 & 0.000 \\
\hline \multirow{5}{*}{ Outputs } & \multirow{4}{*}{$\begin{array}{l}\text { Efficiency and quality in } \\
\text { service provision }\end{array}$} & I 14 & 1133.000 & 3213.000 & -5.897 & 0.000 \\
\hline & & $\mid 15$ & 805.500 & 3016.500 & -7.217 & 0.000 \\
\hline & & $\mid 16$ & 1134.500 & 3412.500 & -6.060 & 0.000 \\
\hline & & । 17 & 1203.500 & 3414.500 & -5.620 & 0.000 \\
\hline & $\begin{array}{l}\text { Modernization of county } \\
\text { public management }\end{array}$ & $\mid 18$ & 1377.000 & 3522.000 & -4.594 & 0.000 \\
\hline \multirow{8}{*}{ Outcomes } & \multirow{2}{*}{ Citizens' satisfaction } & 119 & 987.500 & 3198.500 & -6.539 & 0.000 \\
\hline & & 120 & 1011.500 & 3091.500 & -6.392 & 0.000 \\
\hline & \multirow{3}{*}{ Equity of citizens } & 121 & 1206.000 & 3417.000 & -5.863 & 0.000 \\
\hline & & 122 & 1097.500 & 3242.500 & -6.217 & 0.000 \\
\hline & & 123 & 1187.500 & 3203.500 & -5.543 & 0.000 \\
\hline & \multirow{3}{*}{ Regional development } & 124 & 1487.500 & 3317.500 & -3.838 & 0.000 \\
\hline & & 125 & 1594.500 & 3739.500 & -4.347 & 0.000 \\
\hline & & 126 & 1668.000 & 3684.000 & -3.310 & 0.001 \\
\hline
\end{tabular}

Source: authors 
The results are even more evident when the comparison between the mean ranks of state and county civil servants' answers is examined (Figure 2). There is a considerable difference between the two groups of ranks. County civil servants' mean ranks almost never score lower than 80 , while the mean ranks of state civil servants do not exceed the score of 67 . The only situation in which the ranks are approximately the same (67.11 for state civil servants and 73.44 for county civil servants) is the indicator 14 .

Figure 2: Comparison of mean ranks

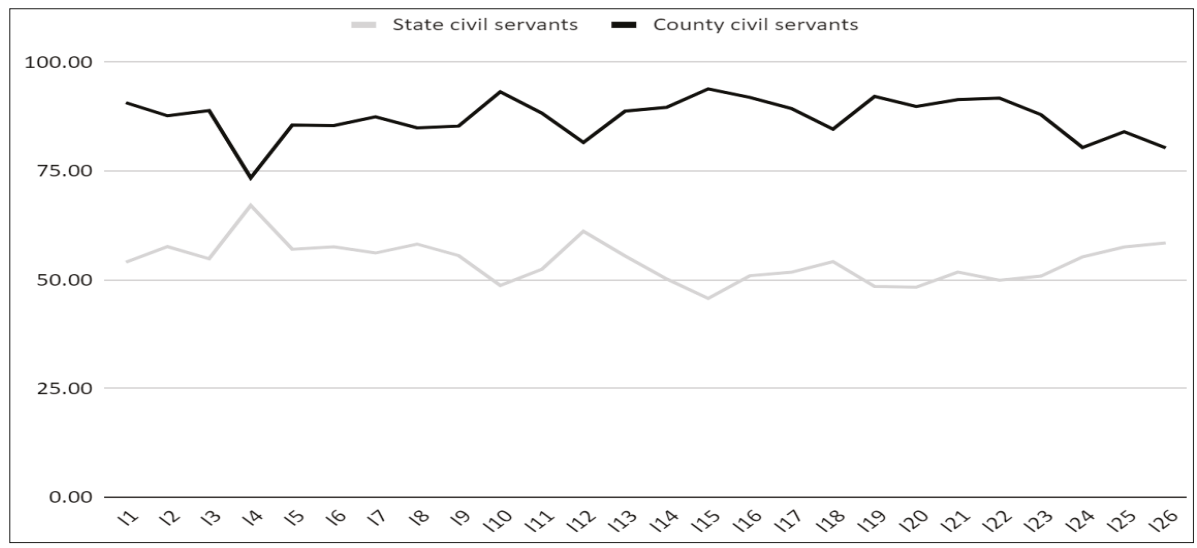

Source: authors

\section{Discussion}

The initial hypothesis that state and county civil servants' predictions on the effects of administrative decentralization differ is confirmed. The question raised is which factors affected the differences between the state and county civil servants' predictions. Taking into consideration the low capacities and the unsatisfactory territorial division of counties, previous experiences with decentralization, and the implementing nature of the transferred tasks, the predictions on the effects of administrative decentralization based on objective knowledge would be that the effects of decentralization would be small. However, county civil servants predict greater effects of administrative decentralization than state civil servants, which opens up space for discussing the possible subjective factors that affected the civil servants' predictions.

The first cognitive factor considered was an organization's interest to survive and expand its power. This factor suggested that county civil servants would predict administrative decentralization to have greater effects on the performance of transferred tasks since this organizational change would ensure the survival of the counties and the growth of their power. It also suggested that state civil servants whose organization was being abolished would predict that the effects of administrative decentralization would be small. The empirical results confirmed this assumption. The second cognitive factor considered 
was uncertainty as an accompanying feature of every organizational change. This factor suggested that those facing greater uncertainty, in this case state civil servants, would predict lesser effects of administrative decentralization than those whose uncertainty is smaller, in this case county civil servants. The empirical results confirmed this assumption, too.

The effect of decentralization on only one indicator (growth of the county governor's role) is similarly predicted by both county and state civil servants. This prediction might have been shaped by both objective and subjective factors. The shift towards strengthening executive power in counties started with the introduction of the direct election of county governors in 2009 which enhanced their position in relation to the county representative body (Koprić and Škarica, 2017) and later with the Amendments to the Act on Local and Territorial (Regional) Self-Government that made the county governors' position even stronger. Due to the legislative amendments, county governors can be recalled only by referendum. If the county budget (which can be proposed by the county governor only) is not adopted, the county representative body will be dissolved but the governor will remain in position (Koprić, 2017). No governor has ever been recalled and there were no recall referenda for governors' recall either. On the other hand, in 2019 the representative body of one county was dissolved while the governor remained in power. ${ }^{5}$ The abolition of county state administration offices strengthens the position of county governors since they direct and supervise county offices that execute the transferred tasks, appoint their heads, and may control the recruitment of new staff. Besides logical reasoning, the county civil servants predicted a greater effect on this indicator also because the growth of the county executive layer would enhance the position of the counties in the Croatian politicaladministration system. The state civil servants' predictions about this indicator might also be explained by the fact that they do not see it as something positive. The growth of the county governors' role means a decrease in the power of the county representative body, with possible negative effects such as the greater discretionary power of county governors and the politicization of county administration.

The empirical results show that the predictions expressed by state civil servants are more in line with the predictions that would be grounded on objective evidence about the characteristics of the Croatian local-self-government system and the characteristics of tasks transferred to the county government. They are also in line with the predictions on the effects of decentralization stemming from decentralization theory. Since administrative decentralization represents only a modest form of restructuring intergovernmental relations, its effects should be lower than the effects of political decentralization in relation to most performance dimensions (democratic control and accountability, and vertical and horizontal coordination). It should only lead to greater efficiency in the provision of services and growing heterogeneity (Reiter et al., 2010, p. 172). However, the empirical evidence from other countries (Czech local units, smaller German counties) suggests that the effects of ad-

5 <https://www.izbori.hr/site/UserDocsImages/482> accessed 30 October 2020. 
ministrative decentralization in local units with small capacities, as in the case of Croatian counties, are mixed, some of them being a decrease in efficiency and quality in service provision, higher costs, weakening of vertical coordination, and great challenges for ensuring horizontal coordination (Ebinger and Richter, 2015). However, it cannot be stated whether the predictions of state civil servants were primarily shaped by objective or subjective factors, since both factors suggested smaller decentralization effects.

\section{Conclusion}

The purpose of the paper is to examine whether there is a difference between the predictions of state and county civil servants on the effects of the abolition of county state administration offices and the transfer of their tasks to counties as second-level self-government units, and what factors shape those predictions. The statistical analysis of the data on the anticipated effects of administrative decentralization indicates that the predictions of the two groups differ in relation to each category (democratic control, accountability and transparency of work of county government; vertical and horizontal coordination; efficiency and quality in service provision and modernization of county public management; citizens' satisfaction, equality of citizens and regional development) and in relation to each of the 26 indicators with only one exception. Both groups of respondents predict the growth of the county governor's role.

Reasoning based on objective factors (features of the Croatian local selfgovernment system and the characteristics of the tasks transferred to county governments) should lead to similar predictions of both groups of respondents. However, their predictions differ. Thus, it may be assumed that the difference in their predictions stem from two subjective factors of cognitive biases. The predictions of county civil servants that administrative decentralization will have greater effects are influenced by the interest of their organization to survive and expand its power. On the other hand, state civil servants' predictions are influenced by three types of uncertainty (strategic, structural, and job-related) which led them to predict lesser effects of administrative decentralization.

The paper offers a twofold theoretical contribution. On the one hand, it provides a theoretical insight into the factors that could shape civil servants' predictions. On the other hand, it adds to the body of literature dealing with administrative decentralization by giving data on the predictions of the actors related to this organizational change before it is implemented. However, there are some limitations to the study. First, the research deals only with top civil servants. Therefore, their predictions cannot be generalized for all levels of civil servants working in these organizations. Second, although the empirical data collected and analyzed offer the possibility to prove statistically that there is a difference in the predictions between the two groups of respondents, they do not give empirical evidence on the factors that have actually shaped these predictions. 
Therefore, the paper opens space for further research in at least three ways. First, further empirical research might be conducted to examine whether the factors of cognitive biases discussed in this paper are the only possible explanation for such a discrepancy in expectations or whether other factors may be included and tested empirically. Second, it will be interesting to test which set of predictions (those of state or county civil servants) will be closer to the real effects of this organizational change. In 2019, just before the abolition of county state administration offices, an ex-ante evaluation of this organizational change was conducted. This evaluation took into account official documents presenting and introducing the abolition of county state administration offices, the predictions expressed by state and county civil servants, the predictions expressed by county governors, parliamentary discussions, comments expressed during the e-consultation process, media reports on the subject and scientific and professional papers written by experts in the field. The evaluation indicated many flaws in the process and, most importantly, that the main goals of this organizational change, officially formulated as rationalization and decentralization, would not be achieved. Additionally, the ex-ante evaluation showed that the effects of the organizational change would be the strengthening of the county governors' role leading to the politicization and petrification of county administration; problems in implementation; inequality in service provision between counties; new financial burdens for counties; and citizens receiving a wider range of services in the same place (Lopižić and Manojlović Toman, 2019). Further ongoing and ex-post evaluations are needed to assess the real effects. Finally, further research is necessary to assess which intervening factors shape the final effects of this type of organizational change in Croatia as compared to other countries undergoing similar administrative decentralization. 


\section{References}

Babić, Z. (2018). Decentralizacija socijalne skrbi i socijalne nejednakosti: slučaj Hrvatske. Revija za socijalnu politiku, 25(1), pp. 25-47. https://doi. org/10.3935/rsp.v25i1.1458.

Bjørnå, H. and Jenssen, S. (2006). Prefectoral Systems and Central-Local Government Relations in Scandinavia. Scandinavian Political Studies 29(4), pp. 308-332. https://doi.org/10.1111/j.1467-9477.2006.00154.x.

Bidwell C.E. and Kasarda J.D. (1998). An ecological theory of organizational structuring. In M. Micklin and D. L. Poston, eds., Continuities in sociological human ecology - The Springer Series on Demographic Methods and Population Analysis. Boston: Springer, pp. 85-116. https://doi. org/10.1007/978-1-4757-9841-8_6.

Bordia, P. et al. (2004). Uncertainty during organizational change: types, consequences, and management strategies. Journal of Business and Technology, 18(4), pp. 507-532. https://doi.org/10.1023/ B:JOBU.0000028449.99127.f7.

Bouckaert, G. and Halligan, J. (2008). Managing Performance: International Comparisons. New York: Routledge, Taylor \& Francis Group.

CoE (2015). Report on European practice and legal framework on prefect institution, local government in emergency situations. At <http://www. slg-coe.org.ua/wp-content/uploads/2015/10/CoE-REPORT_On-Europeanpractice-and-legal-framework-on-prefect-institution_local-government-inemergency-situations_CELGR-LEX-2_2015_.pdf>, accessed 30 October 2020.

Croatian Chamber of Commerce (2018). BDP po županijama. At <https://www. hgk.hr/documents/bdp-po-zupanijama-u-2015-godini-final25ad8955342dfa. pdf $>$, accessed 30 October 2020.

Đulabić, V. (2007). Regionalizam i regionalna politika. Zagreb: Društveno veleučilište u Zagrebu.

Đulabić, V. (2015). Regionalni razvoj i županije u Hrvatskoj. In J.Barbić, ed., Nova upravno-teritorijalna organizacija Hrvatske. Zagreb: HAZU, pp. 139-159.

Đulabić, V. (2018). Harmonizacija regionalne samouprave u Europi i regionalno pitanje u Hrvatskoj. In I. Koprić, ed., Europeizacija hrvatske lokalne samouprave. Zagreb: Institut za javnu upravu, pp. 447-470.

de Vries, M. S. (2013). The effects of reorganizations on reform fatigue: public sector employees. At <https://www.nispa.org/files/conferences/ speeches/201304191553120.nispa\%202013\%20De\%20Vries\%20Reform_ fatigue.pdf>, accessed 30 October 2020.

Ebinger, F., Grohs, S. and Reiter, R. (2011). The performance of decentralization strategies compared: an assessment of decentralization strategies and their impact on local government performance in Germany, France and England. Local Government Studies, 37(5), pp. 553-575. DOI: 10.1080/03003930.2011.604557.

Ebinger, F. and Richter, P. (2015). Decentralizing for performance? A quantitative assessment of functional reforms in the German Lander. International Review of Administrative Science, 82(2), pp. 1-24. DOI: 10.1177/0020852315586916.

Huerta Melchor, O. (2008). Managing change in OECD governments: an introductory framework. OECD Papers on Public Governance, No. 12, OECD Publishing. At <http://www.oecd.org/gov/42142231.pdf>, accessed 30 October 2020. 
Jambrač, J. (2017). Funkcionalna decentralizacija u Hrvatskoj: petnaest godina poslije. Hrvatska I komparativna javna uprava, 17(2), pp. 189-216. https://doi. org/10.31297/hkju.17.2.5.

Koprić, I. (2010). Stanje lokalne samouprave u Hrvatskoj. Hrvatska javna uprava 10(3), pp. 665-681.

Koprić, I. (2015). Teritorijalna organizacija Hrvatske: prema novom uređenju. In J. Barbić, ed., Nova upravno-teritorijalna organizacija Hrvatske. Zagreb: HAZU, pp. 21-45.

Koprić, I. (2017). Novela Zakona o lokalnoj i područnoj (regionalnoj) samoupravi iz 2017. In I. Koprić, ed., Europeizacija hrvatske lokalne samouprave. Zagreb: Institut za javnu upravu, pp. 57-102.

Koprić, I. (2019). Novi zakoni o državnim službenicima i sustavu državne uprave. Hrvatska i komparativna javna uprava, 19(2), pp. 7-14 (Special issue).

Koprić, I. et al. (2014). Upravna znanost - Javna uprava u suvremenom europskom kontekstu. Zagreb: Pravni fakultet Sveučilišta u Zagrebu.

Koprić, I. and Škarica, M. (2017). Evaluacija neposrednog izbora načelnika i župana u Hrvatskoj nakon dva mandata: korak naprijed, dva nazad. In S. Gongeta and M. Smoljić, eds., Zbornik radova 7. međunarodne konferencije 'Razvoj javne uprave. Vukovar: Veleučilište 'Lavoslav Ružička', pp. 156-172.

Koprić, I. et al. (2017). Croatia: Elections for weak counties when regionalization is not finished yet. In A. H. Schakel and R. Dandoy, eds., Regional and national elections in Eastern Europe. Territoriality of the vote in ten countries. London: Palgrave Macmillan, pp. 57-81. https://doi.org/10.1057/978-1-13751787-6_3.

Koprić, I., and Đulabić, V. (2018). Evaluation of the decentralisation programme in Croatia: expectations, problems and results. In I. Koprić, H. Wollmann and G. Marcou, eds., Evaluating reforms of local public and social services in Europe: more evidence for better results. Palgrave Macmillan, https://doi. org/10.1007/978-3-319-61091-7.

Kuhlmann, S. (2015). Administrative reforms in intergovernmental setting: impacts on multi-level governance from a comparative perspective. In E. Ongaro, ed., Multi-level governance: the missing linkages. Bingley: Emerald Group Publishing Limited, pp. 183-215. https://doi.org/10.1108/S2045794420150000004008.

Kuhlmann, S. and Wollmann, H. (2011). The evaluation of institutional reforms at sub-national government levels: a still neglected research agenda. Local Government Studies, 37(5), pp. 479-494.

Kuhlmann, S., Grohs, S. and Bogumil, J. (2014). Reforming public administration in multilevel systems: an evaluation of performance changes in European local governments. In E. Bohne et al., eds., Public administration and the modern state. Palgrave Macmillan, London, pp. 205-222. https://doi. org/10.1057/9781137437495_14.

Kuhlmann, S. and Wayenberg, E. (2016). Institutional impact assessment in multilevel systems: conceptualizing decentralization effects from a comparative perspective. International Review of Administrative Sciences, 82(2), pp. 233254. http://dx.doi.org/10.1177/0020852315583194.

Kuipers, S., Yesilkagit, K. and Carroll, B. (2018). Coming to terms with termination of public organizations. Public Organization Review, 18, pp. 263-278. https:// doi.org/10.1007/s11115-017-0376-4. 
Lopižić, I. (2020). Uloga ureda državne uprave u županijama u hrvatskome upravno-političkom sustavu. Hrvatska i komparativna javna uprava 20(3), pp. 549-577. https://doi.org/10.31297/hkju.20.3.6.

Lopižić, I. and Manojlović Toman, R. (2019). Prethodna evaluacija ukidanja ureda državne uprave u županijama. Zbornik Pravnog fakulteta u Zagrebu, 69(5-6), pp. 835-870. https://doi.org/10.3935/zpfz.69.56.09.

Marčetić, G. (2013). Novo lokalno službeničko pravo i upravljanje ljudskim potencijalima u reformiranoj lokalnoj samoupravi. In I. Koprić, ed., Reforma lokalne i regionalne samouprave u Republici Hrvatskoj. Zagreb: Pravni fakultet Sveučilišta u Zagrebu, Studijski centar za javnu upravu i javne financije, pp. 189-218.

Ministry of Public Administration (2016). Izvješće o radu ureda državne uprave u županijama za 2015. godinu. At <https://uprava.gov.hr/pristupinformacijama/strategije-planovi-i-izvjesca/izvjesca/1055> accessed 28 October 2020.

Ministry of Finance (2019). Izvršenje lokalnog proračuna. At <https://mfin.gov. hr/istaknute-teme/lokalna-samouprava/financijski-izvjestaji-jlp-r-s/203>, accessed 28 October 2020.

Morgan, G. (2006). Images of organizations. Thousand Oaks: SAGE Publications.

Reiter, R. et al. (2010). Impacts of decentralization: the French experience in a comparative perspective. French Politics, 8(2), pp. 166-189. DOI: 10.1057/ fp.2010.5.

Simon, H.A. (1990). Bounded rationality. In J. Eatwell, M. Milgate, P. Newman, eds, Utility and probability. London, UK: The New Palgrave, Palgrave Macmillan. https://doi.org/10.1007/978-1-349-20568-4_5.

UCLG (2016). Croatia. At <http://www.uclg-localfinance.org/sites/default/files/ CROATIA-EUROPE-V3.pdf>, accessed 30 October 2020.

Van Dooren, W., Bouckaert, G. and Halligan, J. (2015). Performance Management in the Public Sector. London: Routledge, Taylor \& Francis Group. https://doi. org/10.4324/9781315817590.

Van de Walle, S. et al. (2016). Comparative research in public administration and the contribution of the COCOPS Top Executive Survey. In G. Hammerschmid, S. Van de Walle, R. Andrews, R., and P. Bezes, eds., Public administration reforms in Europe: the view from the top. Cheltenham, UK: Edward Elgar, pp. 1-11. https://doi.org/10.4337/9781783475407.

Wynen J. et al. (2019). How multiple organizational changes shape managerial support for innovative work behavior: evidence from the Australian public service. Review of Public Personnel Administration, First Published online 10 February 2019, pp. 1-25. https://doi.org/10.1177/0734371X18824388. 